\title{
A márkázás hatásainak vizsgálata a fogyasztói magatartásra két FMCG vállalat példáján keresztül
}

\author{
T. GÁL ${ }^{1}, A$. SZENDI ${ }^{1}$, G. ÁRVÁNÉ VÁNYI ${ }^{1}$ \\ 1Debreceni Egyetem, Gazdaságtudományi Kar, Gazdálkodástudományi Intézet, \\ gal.timea@econ.unideb.hu
}

\begin{abstract}
Absztrakt: Az elmúlt években a cégek felismerték az imázs fontosságát, amelyet képviselnek és a termékük márkáinak épitése mellett el kezdtek koncentrálni a vállalati márka formálására is. Jelen tanulmányban a vállalati márkák világát térképeztük fel két FMCG (gyorsan mozgó fogyasztási cikkek) vállalat példáján keresztül. A kutatás célja, hogy megvizsgáljuk a fogyasztók és a márkák, valamint a termékmárkák és a vállalati márkák közötti kapcsolatot, vagyis hogy hogyan befolyásolja a vállalati márka a fogyasztókat a vásárlási döntések meghozatalánál. A vásárlók céggel kapcsolatos ismeretét is megvizsgáltuk a vásárlási szokásokra. Feltételeztük, hogy a fogyasztók szempontjából a termékek közötti választást gyakran a termék és annak a márkájával kapcsolatos érzések befolyásolják és kevésbé a vállalati márkáé. Ennek ellenére, ha egy vállalat erős vállalati márkával bír, amely köré egy eszmét építettek, amelynek az üzenete hatékonyan van kommunikálva, akkor a vállalati márka létfontosságú lehet a döntéshozásnál.
\end{abstract}

Abstract: Over the last few years, companies have realised the significance of the image they represent and besides building the brands of their products, they started to concentrate on forming the brand of the company.We wanted to examine the world of corporate brands at two FMCG (fast moving consumer goods) companies. The aim of there search was to discover the connection between consumers and brands, product brands and corporate brands; how corporate brand influences customers during purchased ecision making. The effect of consumers' knowledge was also observed about the companies on consumers' habits. We have assumed that from the viewpoint of some customers, choosing among several products is often based on the perception of the brands and products alone and it has little to do with the corporate brand. Although, if one of the companies has a strong corporate brand, an idea built around it, and its message is communicated effectively, when it comes down topic king sides, the brand of the company could be essential to decision-making.

\section{Szakirodalmi áttekintés}

Habár a vállalati márkázás, a vállalati hírnév és a hírnév menedzsment felkapott kifejezések üzleti körökben, gyakran különböző emberek számára különböző dolgokat jelentenek.

ARGENTI és DRUCKENMILLER [2004] a vállalati márkát olyan márkaként definiálja, amely átíveli az egész vállalatot (amely mögött szintén lehetnek termékmárkák). Ez tükrözi azokat az elvárásokat, amelyeket a cég termékek, szolgáltatások és vásárlói tapasztalatok formájában közvetíteni fog és inspiráló hatása is lehet. Tehát a vállalat akkor elkötelezett a vállalati márka iránt, amikor a cég magát, mint márkát dobja a piacra. 
Egy cég vállalati márkája elvárásokat támaszt a fogyasztóknak arról, hogy mit fog a vállalat nyújtani. A márkanév és a logó csak két eleme a vállalati márkázásnak; általában a cégek további kulcselemként vállalati reklámozást használnak a vállalati márka megerősítéséhez.

A vállalati márkázás csak néhány éve került reflektorfénybe, amikor 2001-ben a Business Week és az Interbrand rangsorolta a legjobb világmárkákat, amelydollárban számszerűsítette a legnagyobb világcégek márkáinak értékét [ARGENTI-DRUCKENMILLER, 2004].

KNOX és BICKERTON [2003] a vállalati márkát úgy definiálja, mint „egy szervezet egyedülálló üzleti modelljét, amely kifejezi a cég vizuális, verbális és viselkedési jellemzőit”. A két szerző tanulmányában a vállalati márkázás hat dimenzióját azonosította be [1. ábra].

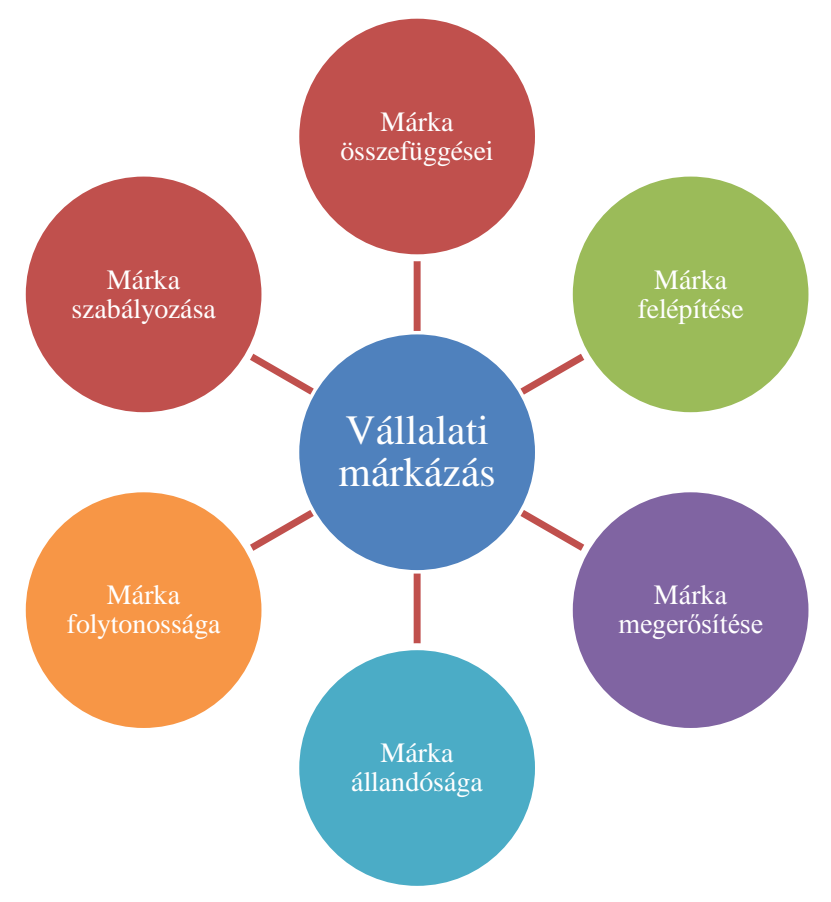

1. ábra: A vállalati márka 6 dimenziója

(Forrás: KNOX-BICKERTON, 2003)

Habár a vállalatnevek könnyen használhatóak a vállalat termékeinek és szolgáltatásainak márkázására, azonban a cégnevek ritkán nyújtanak kielégítő megoldást arra, hogy hatékony és jelentőségteljes üzenetet közvetítsen a márkáról.

A sikeres vállalati márka menedzsment gyakorlatok két tényező beazonosításától függnek: egyrészről a változók összetételétől, amelyek a vállalati márkát alkotják, és másrészről egy márka menedzselési rendszer kifejlesztésétől, hogy megértsük a folyamat irányát és ellenőrizni tudjuk azt [KNOXBICKERTON, 2003].

HATCH és SCHULTZ [2003] szerint egy erős vállalati márka vonzó és közvetíti a közönségnek és a részvényeseknek a felismerhető értékeket és szimbólumokat, ami megkülönbözteti a szervezetet másoktól. De a vállalati márkázás nem csak a megkülönböztetésről szól, hanem a hovatartozásról is. Ha a vállalati márka hatékonyan múködik, az azért van, mert közvetíti az értékeket és/vagy vágyak forrásait, amelyek vonzzák a fő részvényeseket a vállalathoz és ösztönzi őket, hogy a hovatartozást 
érezzék. Ezek a tényezők hatással vannak a döntésekre és a viselkedésre, amelyre a szervezetet építik [2. ábra].

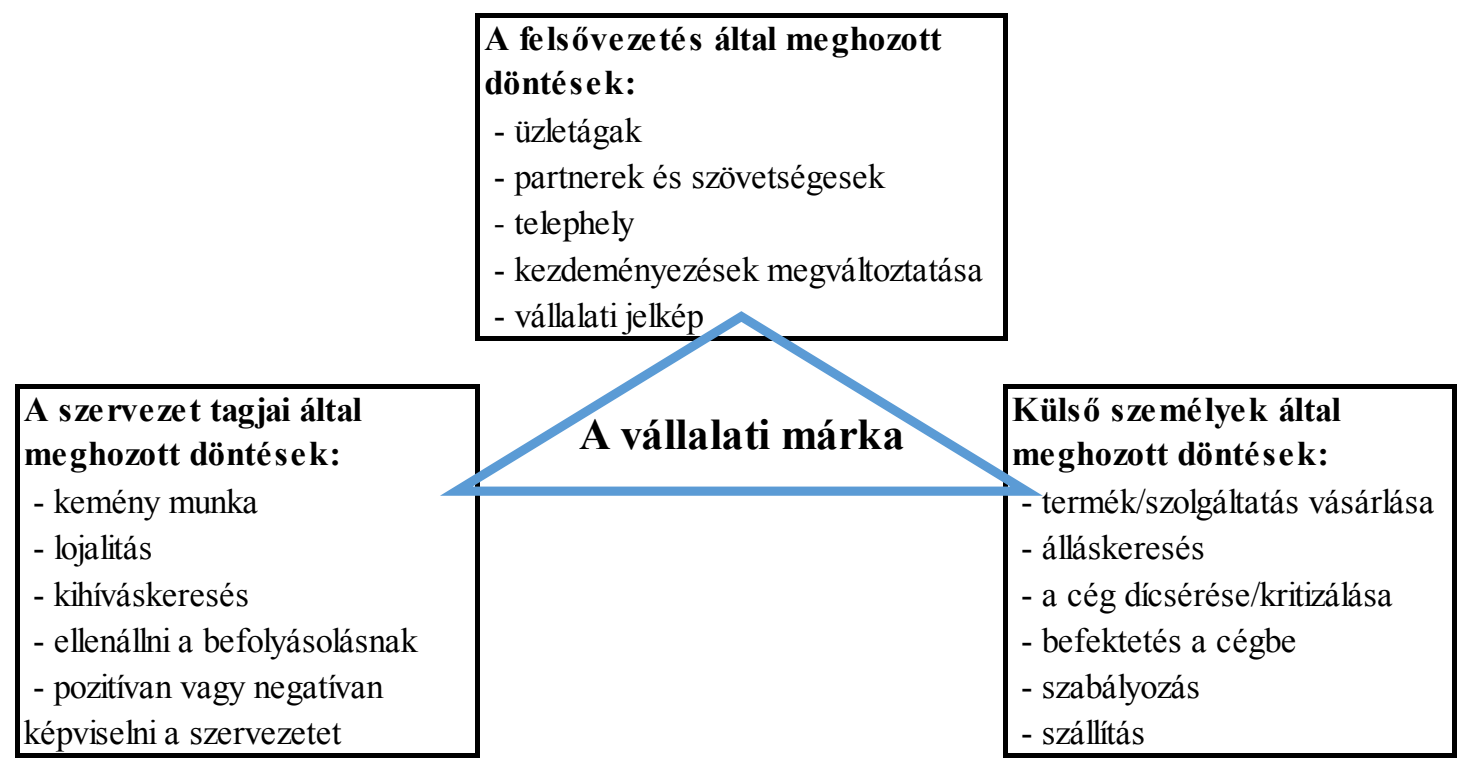

2. ábra: Döntések és a vállalati márka

(Forrás: HATCH-SCHULTZ, 2003)

Egy erős vállalati márkának vonzóereje van és olyan szimbólumokkal rendelkezik, amely elősegíti, hogy az érdekeltek megtapasztalják és kifejezzék az értékeiket és ezáltal aktívan tartsa őket.

A vállalati márkázás kerete olyan folyamatokon alapszik, amely összeköti a stratégiai víziót, a szervezeti kultúrát és a vállalati imázst. Az előbbiekben felsorolt három elem definíciója a következő:

- A stratégiai vízió olyan eszme a vállalat mögött, amely megtestesíti és kifejezi a felső vezetés arra vonatkozó vágyát, amit el fog érni a cég a jövőben.

- A szervezeti kultúra magába foglalja a belső értékeket, hitet és alapvető feltételezéseket, ami képviseli a vállalat örökségét és közvetíti ezeket a tagok felé; a kultúra maga tanúsítja azt, hogy a személyzet hogyan érez a cég iránt.

- A vállalati imázsok képviselik az érdekeltek által kialakított nézeteket és a külső személyek (vevők, média, a nyilvánosság, stb.) benyomásait a cégről.

HATCH és SCHULTZ [2003] szerint az a vállalati márka válhat leginkább sikeressé, amely közvetlenül összekapcsolja a stratégiai vízióját a szervezeti kultúrával.

A vállalati márkázás az, ahogyan a vállalat kommunikálja az identitását. Egy erős és megbízható vállalati márka fontos eleme bármilyen szervezet sikerének. A vállalati márka biztosíték a minőségre, mintegy garanciát vállal az alacsony teljesítmény ellen vagy a pénzügyi kockázatra. A vállalati márka beazonosítást, megkülönböztetést és pozícionálást jelent a szervezetnek, ami egyetlen egységesített üzeneten alapszik, hogy bizalmat építsen a szervezetben. Az eredetiség, különlegesség és megkülönböztethetőség forrása a szervezet öröksége és azok az értékek és hitek, amely közös a vállalatban és az érdekeltekben. 
A vállalati márkázásra belülről úgy tekintenek, ami üzeneteket közvetít egy vágyott kultúráról és kívülről a további fogyasztók vágyairól, hogy mélyebben belelássanak a szervezetbe. A vállalat ajánlatain keresztül történő tisztelet és bizalomépítés a cég célja, hogy ösztönözze a fogyasztókat, hogy elfogadják a cég ígéreteit az ajánlatra vonatkozóan.

A vállalati márka olyan, mint a cég marketingtevékenységének összegzése, amely bizonyítja a cég értékeinek és identitásának meglétét. Ez eltér a termékmárkától stratégiai fókuszában és megvalósításában, amely kombinálja a vállalati stratégiát, a kommunikációt és a kultúrát [ALIZADEH et al., 2014].

\subsection{A vízió, a misszió, az értékekés a vállalati márka kapcsolata}

Számos cég felismerte a vízió értékét már évekkel ezelőtt, de ezt főként a cégek éves jelentésében és honlapján lehet látni, amikor elkezdik kialakítani a vállalati márkájukat. A vízió és az értékek közötti kapcsolat a kulcsa annak, hogy megértsük a szerepüket a vállalati márkára vonatkozóan. Az értékeket a víziónak kell vezérelnie. A vízió, ami belülről hajtja a céget, lehet az a vízió is, ami a külső érdekelteket fogja abba az irányba vinni, hogy higgyenek a cégben és a piacpotenciállal kapcsolatos víziójukban.

A vízió értéke nem magában a vízióban van, hanem az irányokban és a müködésben, amit a cégnek ad. A legfőbb kihívás a cg számára, hogy a víziót tettekbe ültesse át: először a márka részéről a víziót a márka értékébe fordítsa ár és másodjára, hogy az érintettek befektessenek a márkába.

A vízió nem „működik” magától. A vízió cselekedetek nélkül olyan, mint egy üres ígéret a cég érintettjeinek. A 3.ábra aztmutatja be, hogy a víziót hogy lehet megvalósítani a vállalati márkában.

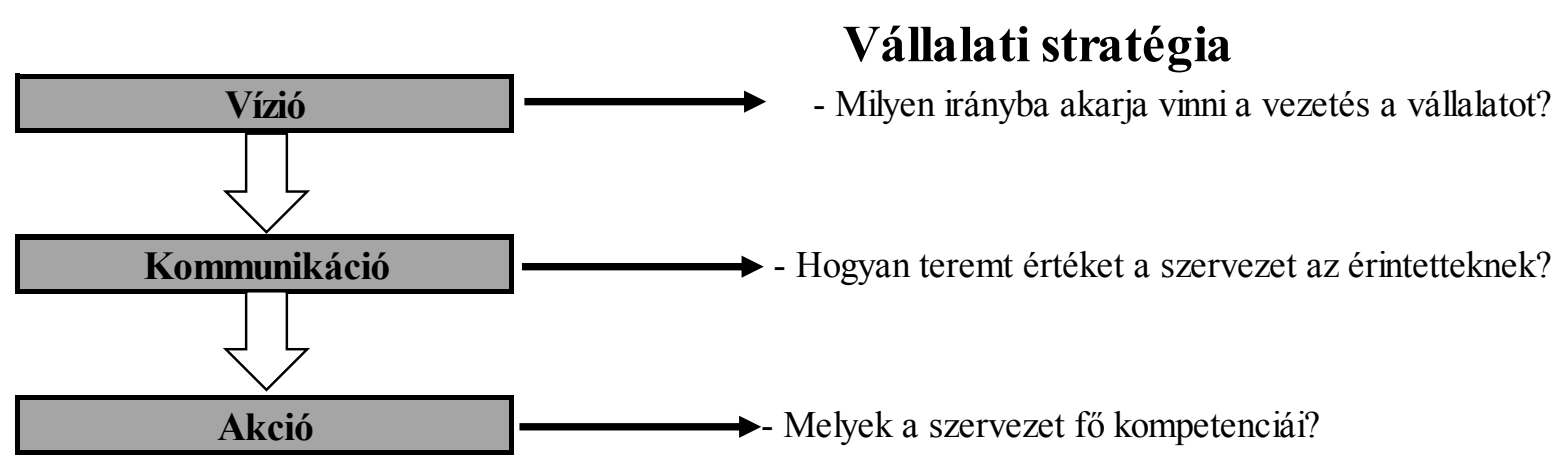

3. ábra: A vízió megvalósításának lépései

(Forrás: JONES, 2010)

A modellnek három eleme van: vízió, kommunikáció és akció. Ezek a vállalati stratégiához kötődnek olyan kérdésekkel, amiket a vezetőknek kell megválaszolniuk. Ebben a három fázisú folyamatban a menedzsment kifejezi a víziót és előreviszi a vállalatot. Ha a víziót megfogalmazták, akkor ezt kommunikálni kell és el kell fogadtatni a cég különböző érdekeltjei felé. A vállalat stratégiai prioritásaitól függően ezek az érdekelt felek lesznek a menedzsment tagja, munkavállalók, beszállítók, 
ügyfelek, stb. Az egyes csoportokkalvalókommunikációnakkülönbözőfókuszúnakkelllennieaszerint, hogy milyen értéket teremt számukra. A fogyasztók esetében ez azt jelenti, hogy a kommunikációnak kevésbé kellene a cég jelenlegi víziójára koncentrálnia, hanem sokkal inkább arra, hogy hogyan fejeződik ez ki a céggel kapcsolatos tapasztalatokban. Ha már biztosak vagyunk abban, hogy a víziót ismerik, elfogadják és jelentéstartalma van, akkor ezután a cégnek meg kell bizonyosodnia arról, hogy ez tettekkel is alá van támasztva. Ebben az esetben az akciót a vállalat belső és külső tevékenységei, valamint az érdekeltek tettei határozzák meg. A cég speciális tevékenysége olyan tevékenységekből fog állni, mint a mérhető célok felállítása a vállalati márkával kapcsolatban, ezeknek a céloknak az elérését elősegítő tettek, és egy értékelő rendszer, ami visszajelzést ad a vállalati márka és annak a víziójának a sikerességéről. A cég érintettjeit a víziónak kell mozgatnia, hogy befektessenek a márkába, ami azt jelenti, hogy nem elég az, hogy a cég rendelkezik márkával, hanem menedzselni kell azt. Ez a befektetés lehet vásárlás, stratégia együttműködés, stb.

A vállalati márkázás egy stratégiai márkázási eszköz, amelynek az a feladata, hogy specifikus eredményeket mutasson fel, amelyek pozitív hatással vannak a vállalat teljesítményére. A vezetés tudatos döntéseket hoz a cég irányításával kapcsolatban és itt a vízió jelentős stratégiai szerepet játszik az értékekre vonatkozóan. A vízió megkülönbözteti azokat a cégeket, akik szúken akarják magukat behatárolni azokkal az értékekkel kapcsolatban, amelyeket a vásárlóiknak teremtenek, azoktól a cégektől, akik a vállalkozást úgy határozzák meg, hogy mit tud az tenni az érintetteknek a jövőben. A vízió kommunikációjának módja ekkor függ a megcélzott érintettek csoportjától, akik felé a cég kommunikál. Jelentést és értéket is teremteni kell mindegyikhez. Végül, a vízióból a tettekbe való átváltás összehasonlítja a víziót a vállalat alapvető kompetenciáival. A víziónak ezeken a kompetenciákon kell alapulnia és kiegyenlítenie azokat, mert anélkül a vízió csak egy üres ígéret. Továbbá minden egyes fázis felosztható további részekre a vállalati márkázási program keretében [JONES, 2010].

\subsection{Vállalati kommunikáció, integrált marketingkommunikáció és vállalati márkázás}

A vállalati kommunikációnak az a célja, hogy körülvegye a különböző érintetteket olyan kommunikációval, ami védetté teszi, vagy legalábbis segít elhatárolni őket más külső befolyásoló tényezőtől. Bármely vállalat középpontjában a vállalati értékek állnak, amelyet képvisel. KITCHEN és SCHULTZ [2003] ezt a vállalati márkának nevezi. Akár támogatja a felső vezetés kommunikációs politikával, akár nem, a vállalati márkák akkor is jelen vannak.

A 21. században a vállalati kommunikációnak kell az összes szervezeti kommunikáció fő elemének lennie, mivel ez az alapja a szervezet irányításának és céljainak. A vállalati értékeket körülveszik a különböző formájú termékmárkák, a hozzákapcsolt integrált márka és marketingkommunikációs programok, amelyek fejleszthetők és közvetíthetők. Ezért a vállalati márkának a vállalati kommunikációs programok középpontjában kellene állnia és az összes kommunikációs formát ehhez kellene kötni és ötvözni azzal. 
KITCHEN és SCHULTZ [2003] az érintetteket (ebben az esetben főleg az ügyfeleket) tekinti bármely integrált kommunikációs tevékenység gyújtópontjának. Őket veszik körül azok a dolgok, amelyeket a vállalat végez és tapasztalataik is nekik lehetnek a céggel kapcsolatban. Például ez magába foglalhatja a termékeket, az árazást, csatornaszereplőkkel való kapcsolatot, vevőszolgálatot, stb.

A vállalati kommunikáció fő célja a nyilvánosság vállalati hirdetésen, vállalati reklámozáson, PR-on, vállalati szponzoráláson, stb. keresztül. Az ilyen tevékenységek célja, hogy támogassa és erősítse a vállalat imázsát - az emberek vállalatról alkotott képét - és identitását - a vállalat erőfeszítéseit, hogy kommunikáljon a célcsoportjaival [KITCHEN-SCHULTZ, 2003].

Amint MADHAVARAM és társai [2005] írják a cikkükben, az integrált marketingkommunikáció nem csak egy kommunikációs folyamat többé, hanem egy olyan folyamat, ami kapcsolatban van a vezetéssel és a márkákkal. Sok szakértő kijelentette már, hogy az integrált marketingkommunikáció számos előnyt nyújt a cégeknek. A szinergián keresztül segít nekik építeni a termékeik és szolgáltatásaik márkaértékét és pozitív hatással lehet egy szervezet márkával kapcsolatos teljesítményére is. Ezáltal az integrált marketingkommunikáció sokkal hatékonyabbá és/vagy hatásosabbá teheti a céget a potenciális célpiacokkal való kommunikációban és segítheti a szervezeteket, hogy magasabb pénzügyi eredményt érjen el a magasabb márkaérték által [MAHDAVARAM et al., 2005].

\subsection{A cég a márka mögött}

Egy új globális kutatás szerint, amit a Weber Shandwick PR cég és kutató leányvállalata a KRC Research végzett el, a márka mögött meghúzódó cég döntő lehet a fogyasztói vásárlói döntéseknél. A felmérést 2011 október-novemberében végezték el 1375 nagykorú fogyasztó bevonásával. A kutatásba bevontak még 575 szenior felsővezetőt, akiknek a cégei 500 millió dollár fölötti éves árbevétellel rendelkeznek. A válaszadókat 4 fontos piacról vonták be: USA, Egyesült Királyság, Kína és Brazília.

A tanulmány beazonosított 6 új tényezőt a vállalati hírnévről, amely világosan állítja, hogy a cég hírnevének és a termékmárkáknak az összehangolása és integrálása optimalizálja az erősségeiket hogy jobb üzleti eredményt érjenek el (SHANDWICK, 2011).

A vállalati hírnév első ténye, hogy „A vállalati márka ugyanolyan fontos, mint a termék márká(k).” A tanulmány megállapította, hogy a felsővezetők legnagyobb része (87\%) hisz abban, hogy egy erős vállalati márka ugyanolyan fontos, mint az erős termékmárkák. Főként azért érzik így, mert azt vallják, hogy a termékmárka esetében előnyt jelenthet a vállalati hírnév és a fogyasztókat érdekli az általuk vásárolt termékmárka mögött lévő cég is (55\%).

Mit gondolnak a fogyasztók a cégről? Minden cégnek tudatában kellene lennie azzal a kutatás által feltárt ténnyel, mely szerint a fogyasztók a vállalati hírnév alapján hoznak vásárlási döntéseket, nem csak a termék vagy szolgáltatás alapján önmagában. A megkérdezett fogyasztók a felmérés során világossá tették, hogy őket érdekli, hogy hol készülnek a termékek, mit tesz a cég, hogy megvédje a környezetet, stb. Vagyis tudni akarják, hogy hova megy a pénzük, amikor azzal támogatnak egy vállalatot, hogy a termékeiket vásárolják. 
A tanulmány szerint a vásárlók 70\%-a elkerüli a vásárlást, ha nem kedveli a gyártó céget. Az is érdekes, hogy a fogyasztók 61\%-a ingerült lesz, ha nem tudja megmondani, hogy melyik cég áll a termék mögött és több mint a megkérdezettek fele (56\%) állította, hogy utánanéz a cégnek, hogy jobban megismerje.

Az ilyen tudatos fogyasztókkal szemben a jó vállalati hírnév döntővé vált. Tulajdonképpen a fogyasztók gyakran használták a „biztosíték” szót, amikor leírták a márka mögötti cég értékét.Mivel a vállalati hírnév minőségi biztosítékká vált, könnyebbé teszi a fogyasztók számára, hogy válasszanak a hatalmas számú lehetőség közül.

Érdekes, hogy a fejlődő országok fogyasztói sokkal inkább foglalkoznak a márka mögötti vállalattal és megkövetelik a címkézés átláthatóságát (SHANDWICK, 2011).

Egy amerikai felsővezető a következőt állította az anya- és a termékmárka kapcsolatáról: „Jelentősnek tekinthetô a népesség azon száma, akik a dollárjaikkal szavaznak. Az embereknek a szülőmárkában is meg kell bízniuk ahhoz, hogy elkötelezzék magukat a termékmárkához."

Bármiféle szétválasztás a szülőmárka és a termékmárka között negatív reakciót válthat ki a fogyasztókból. A vásárlók 40\%-a nem vásárolná többé a terméket, ha felfedeznék, hogy nincs kapcsolat a szülőmárka és a termékmárka között.

Közismert, hogy mások véleménye nagyon erős befolyásoló hatással bírhat. Amikor véleményt kell alkotni a cégről, akkor nem meglepő, hogy a szájreklám a legbefolyásolóbb (88\%) a fogyasztók körében. Azután az online források tekinthetőek a leginkább befolyásolónak (online kritikák - 83\%, online keresési eredmények - 81\%). A hírforrások (79\%) és a céges weboldalak (74\%) szintén kritikusak egy fogyasztó cégről alkotott véleményének formálásában. Ez az eredmény felülírja azoknak a véleményét, akik megkérdőjelezik a céges weboldal hatékonyságát, mivel beigazolódott, hogy ez fontos a vállalati hírnév szempontjából (SHANDWICK, 2011).

A tanulmány más aspektusokat is megvizsgált a vállalati hírnévvel és a termékmárkákkal kapcsolatban, de véleményünk szerint a tanulmány legfőbb eredménye az, hogy a fogyasztók többsége egy erős vállalati márka a végső határ a magas minőségű termékmárkák számára. Tényleg számít nekik, hogy melyik cég termékét vásárolják meg, mert a fogyasztók a kemény munkával megszerzett pénzüket olyan cégekbe szeretnék „befektetni”, amelyeknek eszméjük és értékeik vannak.

\section{Anyag és módszer}

A kutatás során kétféle adattípust különböztetünk meg: primer és szekunder adatokat. A szekunder adatok már korábban gyűjtött információkat dolgoz fel. Azonban a szekunder adatokkal óvatosnak kell lenni, mivel az is lehetséges, hogy a szekunder adatok nem megfelelőek az adott probléma elemzéséhez [KOTHARI, 2004].

A kutató ellenőrzése és felügyelete alatt gyűjtött információkat nevezzük primer adatoknak. Ezeket az adatokat első alkalommal gyűjtötték össze például megfigyelésekkel, személyes és telefonos interjúkkal, kérdőíves megkérdezéssel [PANNEERSELVAM, 2004]. 
A kutatásunkhoz kvantitatív és kvalitatív módszereket is alkalmaztunk: fókuszcsoportos vizsgálatot és kérdőíves megkérdezést használtunk a téma alapos vizsgálatához. Mindkét vizsgálat célja a márkákkal kapcsolatos fogyasztói attitűdök felmérése mellett az volt, hogy két FMCG (gyorsan mozgó fogyasztási cikkek) vállalat márkáinak ismertségét megvizsgáljuk (Procter\&Gamble és Unilever), illetve hogy mennyire tudják beazonosítani a fogyasztók a víziójukat és a missziójukat és a vállalati márkát mennyire tudják összekapcsolni a termékmárkákkal.

A fogyasztóktól az információkat egy 29 kérdésből álló kérdőívvel gyűjtöttük össze a márkázott fogyasztói cikkekkel, a vásárlási döntésekkel és a vizsgált cégekkel kapcsolatos ismeretekkel összefüggésben. A zárt kérdések mellett skálás kérdéseket használtunk a kérdőívben.

A kérdőívet az interneten osztottuk meg és 2 hétig volt elérhető. A kitöltés természetesen önkéntes és anonim módon történt. A vizsgált időszakban 203 kérdőívet töltöttek ki, amelyből 1 kérdőív válaszai nem voltak értékelhetőek. A válaszok kódolását követően az eredményeket az SPSS statisztikai programmal és Microsoft Office Excel programmal elemeztük ki. Az értékelés során különböző számításokat végeztünk és kereszttáblás elemzéseket készítettünk.

A fókuszcsoportos vizsgálatokat azért végeztük el a kérdőíves megkérdezést követően, hogy sokkal pontosabb információkat kapjunk a vizsgált cégek vállalati márkájával, víziójával, missziójával és értékeivel kapcsolatban.

A fókuszcsoportos vizsgálatoknak 3 fő része volt: a fogyasztók kapcsolata a fogyasztói márkákkal és az azokat gyártó vállalatokkal, a válaszadók véleménye a vizsgált cégek víziójáról és missziójáról és a cégek reklámjaival kapcsolatban. Két fókuszcsoportos vizsgálatot végeztünk 7-7 fős csoporttal a kérdőív nem, kor, iskolai végzettség alapján kialakult arányoknak megfelelően.

\section{Eredmények és értékelésük}

\subsection{A kérdőíveredményei}

Összesen 202 fő töltötte ki a kérdőívet értékelhetően, melynek 79\%-a (160 fő) nő és 21\%-a (42 fő) férfi volt. A válaszadók többsége 21 és 30 év közötti, a válaszadók átlagos életkora 40. A válaszadók több mint egyharmada (39\%) él megyei jogú városban, 35\%-a városban, 16\%-a a fővárosban, 6\%-a községben és 3\%-a külföldön. Családi állapotukat tekintve 79\%-uk egyedülálló, 17\%-a házas, a maradék elvált (3\%) vagy özvegy (1\%). A válaszadók többségének (65\%) felsőfokú, egynegyedüknek középfokú végzettsége van. A megkérdezettek 48\%-a nettó 100 ezer forintnál magasabb havi jövedelemmel rendelkezik.

Számos tényező befolyásolja a fogyasztók vásárlási döntéseit [4. ábra]. A minőség állandósága a legfontosabb tényező (85\%) a válaszadók számára a fogyasztói cikkek vásárlásánál. Az ár-érték arány (82\%) majdnem olyan fontos a megkérdezetteknek, mint a minőség állandósága. Ezeket követi a megbízhatóság (56\%), a termék származása (29\%), a szokás (26\%), a termék design-ja, főként a csomagolása (13\%) és végül a gyártó vállalat üzletpolitikája (5\%). 


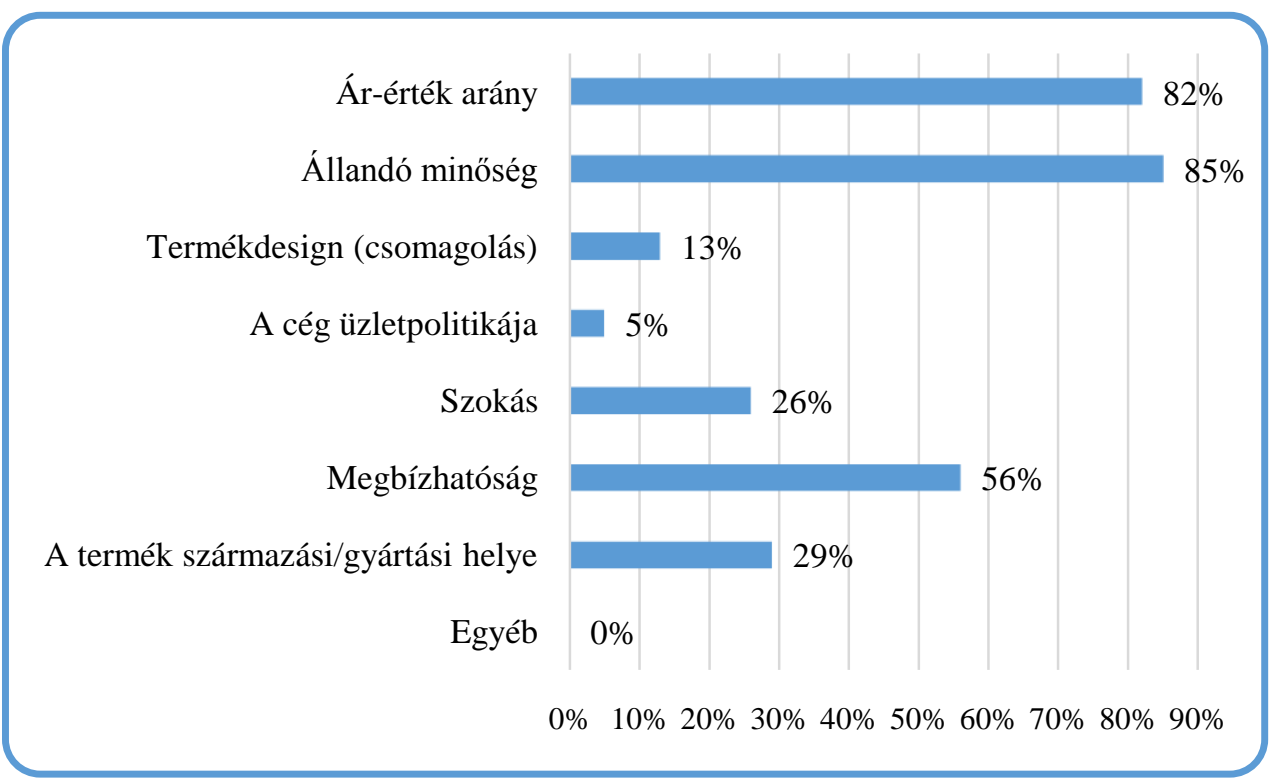

4. ábra: $A$ vásárlói döntést befolyásoló tényezők (n=202)

(Forrás: saját kérdőíves megkérdezés, 2014)

Fontos megvizsgálni, hogy milyen tényezők befolyásolják a különböző korcsoportokat a vásárlási döntések meghozatalánál. A 18-20 év közöttiek (42\%) és az 50 év felettiek (30\%) számára az ár-érték aránya a legfontosabb, míg a többi korcsoport számára - beleértve a 21-30 éveseket (29\%) és a 31-40 éveseket (31\%) - a minőség állandósága áll az első helyen.

Mivel két multinacionális cég vállalati márkáját vizsgáljuk több mint 600 márkával, a kérdőívet kitöltőket arról is megkérdeztük, hogy mi a véleményük gyártói és a kereskedelmi márkákról [5. ábra]. Mivel a fogyasztói cikkek márka portfóliója igen széles, a megkérdezettek gyakran vásárolnak termékeket mindkét márkatípusból (69\%) és csak a válaszadók 14\%-a lojális a gyártói márkákkal.

A kereszttáblás elemzés megerősítette, hogy a jövedelem nem befolyásolja a vásárlási döntést a márkaválasztásnál.

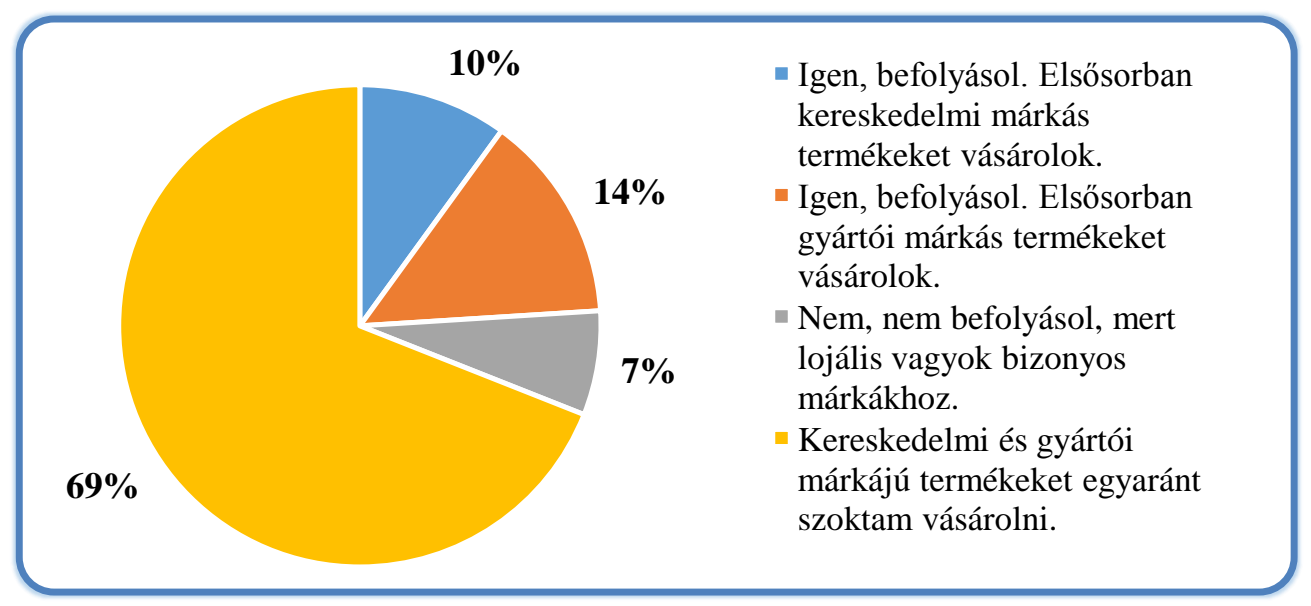

5. ábra: A kereskedelmi márkák és a gyártói termékmárkák hatása a vásárlói döntésekre (n=202)

(Forrás: saját kérdőíves megkérdezés, 2014) 
A válaszadókat ezután megkértük arra, hogy adják meg 1-től 5-ös skálán, hogy mennyire tekintik ezeket a termékeket egymással helyettesíthetőnek, ahol az 1 „egyáltalán nem”-et jelent, az 5 pedig „teljes mértékben”. A válaszok alapján az átlag 2,96, ami a fogyasztók nyitottságát és rugalmasságát jelzi a fogyasztói cikkekkel kapcsolatban.

A kérdőív következő részében számos kérdést tettünk fel a válaszadóknak az FMCG cégekkel való kapcsolatukról.

A válaszadók közel fele (49\%) fontosnak tartja tudni, hogy melyik vállalat gyárt bizonyos előnyben részesített terméket, 32\%-ukat nem érdekli a gyártó és csak 19\%-uk találja általánosságban fontosnak annak ismeretét, hogy melyik szervezet gyárt egy adott fogyasztói cikket.

Megkértük a kérdőív kitöltőit, hogy adják meg 1-től 5-ös skálán, hogy milyen hatással van a vásárlási döntéseikre a cégről előzetesen szerzett információ, amelyre a válaszadók többsége a 3-ast (26\%) és a 4-es értéket (46\%) jelölte meg, az átlag 3,12 lett. Vagyis megállapítható, hogy a válaszadókat többségében inkább befolyásolja a cégről korábban szerzett információ.

A kereszttáblás elemzés eredményei alapján megállapítható, hogy azok a válaszadók, akik korábban azt állították, hogy fontos számukra melyik FMCG cég termékét vásárolják, őket nagyon befolyásolja vásárlási döntéseikben a gyártóról korábban szerzett ismeret [6. ábra].

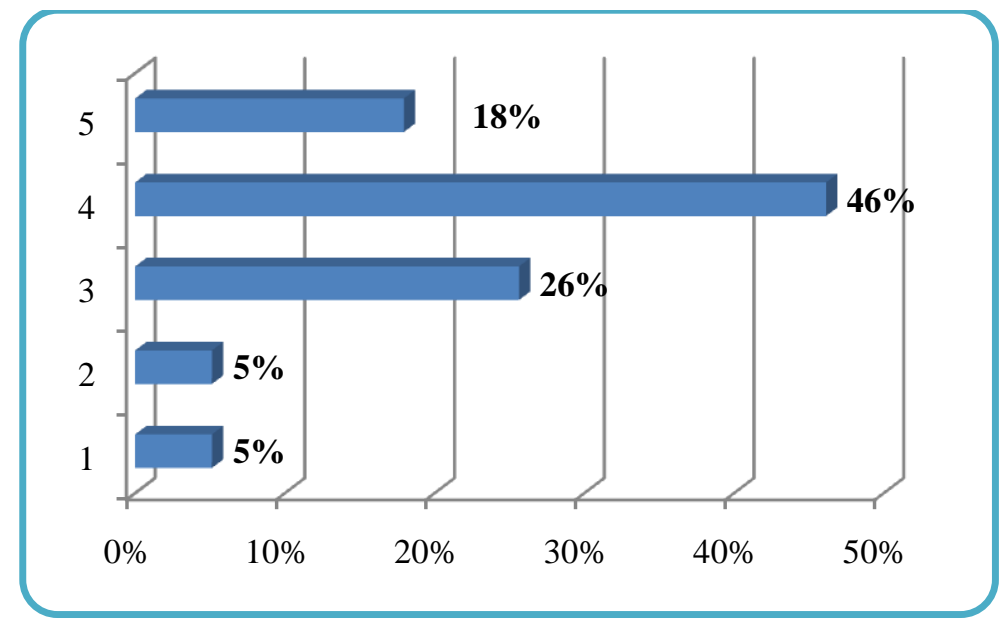

6. ábra: Az FMCG cégek ismeretének fontossága és a korábban szerzett ismeretek hatása a vásárlási döntésre $(n=39)$

(Forrás: saját kérdőíves megkérdezés, 2014)

Számos tényező befolyásolhatja a fogyasztók véleményét az FMCG vállalatokkal kapcsolatban a vállalati kommunikációtól mások véleményéig. A válaszadók többségét a családtagok, barátok véleménye(42\%) és a cég marketingkommunikációja (pl.: hirdetések, szponzorálás, stb.) (34\%) befolyásolja a leginkább. Továbbá néhány válaszadó megemlített egyéb befolyásoló tényezőket is, például a korábbi tapasztalatokat (5\%). A kérdésre kapott válaszokat a 7. ábra mutatja be. 


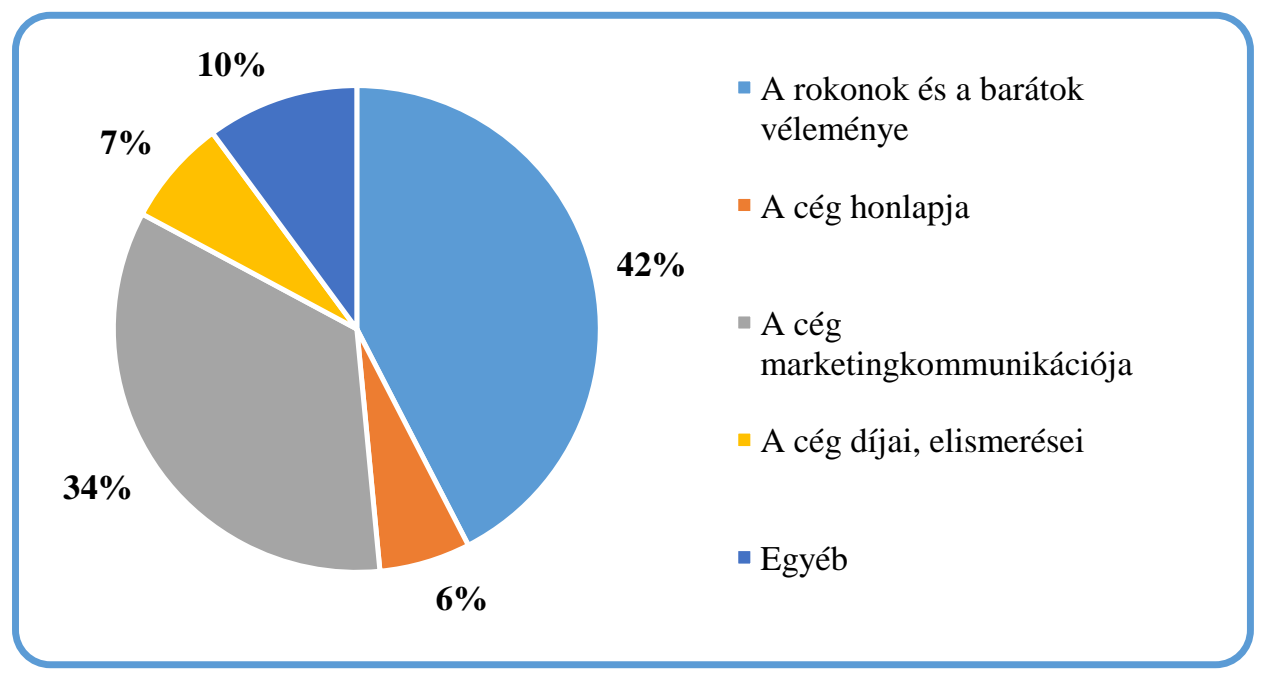

7. ábra: A fogyasztók véleményét befolyásoló tényezók az FMCG cégekkel kapcsolatban (n=202)

(Forrás: saját kérdőíves megkérdezés, 2014)

Ezt követően a kérdőívben a válaszadóknak termékmárka logókat kellett a gyártó cégekkel összepárosítaniuk azért, hogy megvizsgáljuk, hogy a fogyasztók tisztában vannak-e a vizsgált FMCG cégek és az általuk gyártott termékek közötti viszonnyal. A márkákat különböző termékkategóriákból választottuk ki mindkét cég esetében, beleértve népszerű és kevésbé népszerű márkákat is. $\mathrm{A}$ válaszadók nemcsak a két cégből választhattak, ugyanis ha nem voltak biztosak a válaszaikban, akkor a „nem tudom” lehetőségre is voksolhattak.

Az eredmények azt mutatják, hogy a márkák 45\%-át - 11-ből 5-öt - tudták csak a megkérdezettek helyesen a cégekhez társítani. A P\&G esetében 5 termékmárkából 3-at tudott a többség helyesen besorolni [1. táblázat], míg az Unilevernél 6 márkából csupán kettőt tudtak megfelelően hozzárendelni a céghez [2. táblázat]. Megállapítható, hogy azok a termékmárkák, amelyeket többször reklámoznak a médiában, sokkal valószínűbb, hogy hozzá tudják kapcsolni a megfelelő vállalathoz. A vállalati logók feltüntetése a termék csomagolásán és különböző marketinganyagokon (pl. reklámok) megváltoztathatják ezt az állapotot a jövőben. Továbbá, a szervezetek tovább építhetik az image-üket kampányok szervezésével, azzal a céllal, hogy a fogyasztók megismerjék a céget játékos, kreatív módon.

\begin{tabular}{|c|c|c|c|c|c|}
\hline & CHlewe & & Pampers & Orals & Lenor \\
\hline P\&G & $\mathbf{5 7 \%}$ & $30 \%$ & $\mathbf{5 5 \%}$ & $\mathbf{4 9 \%}$ & $36 \%$ \\
\hline Unilever & $4 \%$ & $\mathbf{3 6 \%}$ & $\mathbf{7 \%}$ & $8 \%$ & $17 \%$ \\
\hline Nem tudom & $39 \%$ & $34 \%$ & $38 \%$ & $43 \%$ & $\mathbf{4 8 \%}$ \\
\hline
\end{tabular}

1. táblázat: A P\&G termékmárkáinak ismertsége

(Forrás: saját kérdőíves megkérdezés, 2014) 


\begin{tabular}{|c|c|c|c|c|c|c|}
\hline & Ool & Froor & Coccolino & & & Sigñal \\
\hline P\&G & $29 \%$ & $0 \%$ & $26 \%$ & $15 \%$ & $16 \%$ & $29 \%$ \\
\hline Unilever & $37 \%$ & $69 \%$ & $31 \%$ & $38 \%$ & $31 \%$ & $32 \%$ \\
\hline Nem tudom & $34 \%$ & $31 \%$ & $43 \%$ & $47 \%$ & $53 \%$ & $40 \%$ \\
\hline
\end{tabular}

2. táblázat: Az Unilever termékmárkáinak ismertsége

(Forrás: saját kérdőives megkérdezés, 2014)

Ezután a válaszadókat megkértük arra, hogy értékeljék a vállalatokat 1-től 10-ig, hogy mennyire fontos nekik ismerni a vállalatok misszióját, vízióját és értékeit, ahol az 1 az „egyáltalán nem” és a 10 a „teljes mértékben”. A 202 megkérdezett válaszai alapján az átlag 4,88 lett, ami ezt jelzi, hogy ezek a jellemzők valószínűleg a sokkal fogékonyabb fogyasztókat befolyásolja.

Az előző kérdéshez kapcsolódva, a válaszadóknak össze kellett párosítaniuk a vizsgált FMCG cégeket a víziókkal és missziókkal. Mivel a legtöbb FMCG vállalat ezeket nem kommunikálja közvetlenül inkább a jelenlegi és jövőbeli munkavállalóknak, munkáltatóknak és üzleti partnereknek - ezért a válaszadók többsége nem tudta helyesen hozzárendelni ezeket a két céghez.

Azonban azok a megkérdezettek, akik helyesen párosították össze a víziókat a cégekhez (a „B” vállalatnál 54\%, az „A” vállalatnál 58\%), a missziót is hibátlanul rendelték a vállalatokhoz. Ezért ez a kedvező eredmény abból is adódhatott, hogy egyrészről a víziók és a missziók egymással harmóniában vannak, másrészről a cégek képesek ezeket a kvalitásokat ösztönösen közvetíteni a termékmárkáikon keresztül.

Azok a válaszadók, akik ismerték a „B” vállalat vízióját és misszióját (53 fő), helyesen társítottak a céghez 3 termékmárkát (50\%), míg azok, akik az „A” vállalat vízióját és misszióját határozták meg jól (68 fö), csupán egy márkalogót tudtak a céghez párosítani.

Azonban a misszió, a vízió és az értékek ismeretének fontosságát átlagosnak értékelték a megkérdezettek, ugyanis a válaszadók többsége (45\%) azt állította, hogy a cégeknek tudatosan kellene közvetíteniük a missziójukat, víziójukat és az értékeiket, 38\%-uk fontosnak tartja bizonyos cégek esetében ezeknek az ismeretét és 18\%-uk egyáltalán nem tartja fontosnak [8. ábra]. Ezért az FMCG vállalatoknak meg kellene fontolniuk azt, hogy hogy alakítsák és közvetítsék a víziójukat és missziójukat a fogyasztóknak a belső kommunikációjuk mellett. 


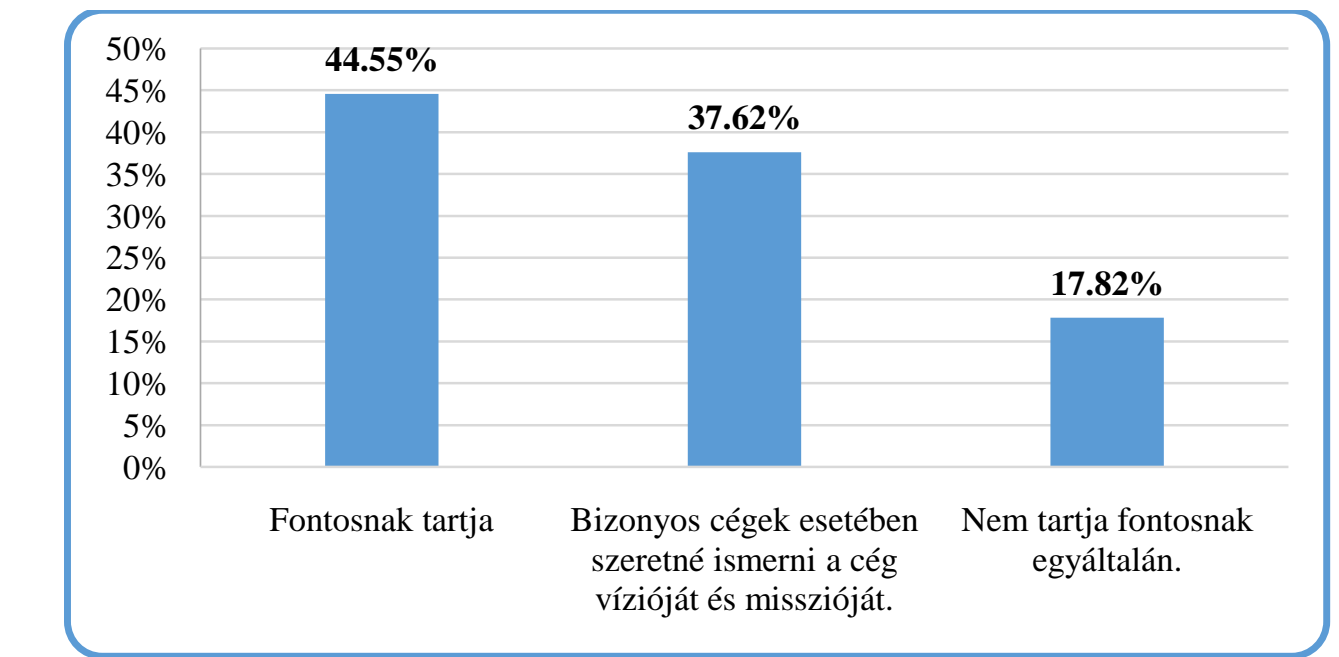

8. ábra: A misszió, a vízió és az értékek közvetítésének fontossága a fogyasztók számára (n=202)

(Forrás: saját kérdőíves megkérdezés, 2014)

A fogyasztókat számos tényező befolyásolja a vásárlási döntéseik előtt és alatt. A kérdőívben, a válaszadókat megkértük, hogy adják meg, hogy melyik marketingeszköz hogyan befolyásolja a vásárlási szokásaikat [3. táblázat]. A legtöbb felsorolt eszköz (pl.: újsághirdetések, TV reklámok, internet, hirdetőtáblák) alig befolyásolja a válaszadókat, míg az ajánlások bírnak a legmeggyőzőbb erővel a fogyasztók száméra, ami megváltoztathatja a vásárlási döntésüket.

\begin{tabular}{|c|c|c|c|c|c|c|}
\hline & Újsághirdetés & Szórólap & Ajánlás & $\begin{array}{l}\text { TV } \\
\text { reklám }\end{array}$ & $\begin{array}{l}\text { Internetes } \\
\text { hirdetés }\end{array}$ & Hirdetőtáblák \\
\hline $\begin{array}{l}\text { Egyáltalán nem } \\
\text { befolyásol }\end{array}$ & $36 \%$ & $51 \%$ & $4 \%$ & $32 \%$ & $33 \%$ & $41 \%$ \\
\hline Kissé befolyásol & $57 \%$ & $42 \%$ & $34 \%$ & $52 \%$ & $53 \%$ & $52 \%$ \\
\hline $\begin{array}{l}\text { Erősen } \\
\text { befolyásol }\end{array}$ & $7 \%$ & $7 \%$ & $62 \%$ & $16 \%$ & $14 \%$ & $7 \%$ \\
\hline
\end{tabular}

3. táblázat: A különböző tényezők hatása a vásárlási döntésekre (n=202)

(Forrás: saját kérdőíves megkérdezés, 2014)

\subsection{A fókuszcsoportos vizsgálatok eredményei}

A fókuszcsoportos vizsgálatokat 2 csoport bevonásával végeztük el. Ahogy azt korábban említettük, a fókuszcsoportban résztvevőket a kérdőívet kitöltők összetétele alapján választottuk ki nem, kor és végzettség alapján. Mindkét csoport 7 főből állt, amelyből 5 nő és 2 férfi volt. A csoportból 4-5 fő volt 21 és 30 év közötti, de a többi korcsoportból (31-40, 41-50 és 50 év feletti) is választottunk ki résztvevőket. A résztvevők többségének (4-5 fő) felsőfokú végzettsége volt, 1 fő vett részt szakirányú továbbképzésben és 1-2 fő rendelkezik középfokú végzettséggel.

Amikor a résztvevőket a fogyasztói cikkeket gyártó cégekkel kapcsolatos ismereteikről kérdeztük, akkor az első csoport azt állította, hogy őket általánosságban nem befolyásolják a vállalatokkal kapcsolatos ismereteik, de a rossz marketing és a botrány hatással lehet a vásárlási döntéseikre a 
fogyasztói cikkek esetében. Azonban a jó híreknek sem lenne ellentétes hatása rájuk: például csak azért nem vennék meg egy adott cég termékét, mert tett valamilyen emberbaráti dolgot.

A másik csoport résztvevőinek nagy részét sokkal inkább érdeklik maguk a termékek, mint a gyártóik. Számukra a termék minősége és eredete fontosabb, ami azt jelenti, hogy inkább előnyben részesítik a magyar termékeket. Egy botrány - főleg a termékek minőségével kapcsolatban - a résztvevők döntését sokkal inkább befolyásolná.

Az 1. csoport résztvevői az internetet arra használják, hogy információt gyűjtsenek a termékekről, sem mint a vállalatokról. Ők általában más fogyasztók véleményét keresik különböző fórumokon, míg más válaszadók inkább a rokonaik és barátaik véleményében bíznak. Egy referenciaszemély szintén befolyásolhatja a véleményüket egy termékről vagy cégről.

A 2.csoport többségét a barátok véleménye befolyásolja a leginkább, míg egy nő említette meg, hogy őt kissé befolyásolják a reklámok, hogy kipróbáljon egy új terméket. Más résztvevők is véleményt formálnak egy cégről, ha kipróbálták az egyik terméküket.

Miután mindkét csoport ismerte a vizsgált vállalatokat, ezért megkértük a résztvevőket, hogy párosítsák össze a termékmárkák logóit a gyártó vállalatokkal (ugyanazokat, mint amelyek a kérdőívben szerepeltek).Az egyik csoport 55\%-ban tudta ezeket helyesen beazonosítani, míg a másik csoport 45\%-ban tudta hibátlanul hozzárendelni a márkákat a cégekhez.

Fontos kiemelni a tényt, hogy a vállalati logó feltüntetése a termékcsomagoláson nagyszerű lehetőség lehet arra, hogy javítsák a fogyasztók tájékozottságát, mivel egy nő résztvevo ismerte az összes „B” vállalathoz tartozó márkát, mert emlékezett, hogy látta a vállalat logóját a termékek csomagolásán.

Ezután a vállalatok vízióját és misszióját kellett beazonosítani a csoportoknak.Az első csoportban a résztvevők 71\%-a tudta helyesen meghatározni a vállalatok vízióját és $57 \%$-uk a cégek misszióját is. A másik fókuszcsoportban ez az arány pont ellentétes volt a másik csoporthoz képest.

A fókuszcsoportos vizsgálat zárásaként különböző reklámokat vetítettünk a vizsgált cégek vállalati márkáival kapcsolatban. A videók megnézése után, a résztvevőket megkértük, hogy osszák meg tapasztalataikat a reklámokkal kapcsolatban, hogy hogyan jelenik meg a vízió és a misszió ezekben és mi a reklám üzenete.

$\mathrm{Az}$ „A” vállalat esetében az első csoport résztvevőinek többsége nem érezte a harmóniát a cég víziója, missziója és a videó között. A férfi válaszadók egyetértettek abban, hogy a film nem volt összhangban a vállalat profitorientált hozzáállásával, mivel a videó a fogyasztók érzelmeire próbált hatni.A női válaszadók egy részét megérintette a reklám. Véleményükszerint a videótükrözte a vállalatimázsát, vagyishogyambiciózus, profiés a magasminőségű termékek legjobb gyártója.

A 2.csoport egyik női résztvevője úgy gondolta, hogy a videó jobban befolyásolja a női fogyasztókat, de mindenkinek tetszett az „A” cég reklámja. A válaszadók többsége elégedett volt a videó fö üzenetével. Az összes résztvevő egyetértett abban, hogy a cég víziója és missziója összhangban van a reklámmal.

A „B” vállalat reklámjának megnézése után az első fókuszcsoportban résztvevők többsége úgy találta, hogy az sokkal inkább összhangban van a cég víziójával és missziójával, mint a másik esetében. A férfi 
résztvevők egyetértettek abban, hogy sokkal inkább azonosulni tudtak a reklám üzenetével.A nők egy részének egyáltalán nem tetszett a videó, mivel számukra ez depresszív volt.

A kezdeményezés minden résztvevő számára szimpatikus volt, azonban a videó nem befolyásolná őket, hogy a cég termékeit vásárolják. Az egyik női résztvevő kihangsúlyozta, hogy jó volt ilyen információkat megtudni a cégről.

$A$ „B” vállalat kezdeményezését üdvözölte a második csoport, de nem keltett mély benyomást bennük a reklám.Néhány résztvevő nem értette a videó koncepcióját és ellentmondásosnak találta. A fö üzenete világos volt, így az egyik női résztvevő szerint ez összhangban volt a „B” vállalat víziójával. Egy másik női résztvevőnek nem tetszett a reklám, mivel véleménye szerint érzelmileg túl nagy nyomást tett a fogyasztókra. Utolsó megjegyzésként, az egyik válaszadó szerint a reklám túl hosszú volt.

\section{Összefoglalás}

Az elvégzett kutatási eredmények alapján megállapítható, hogy a megkérdezettek többsége még mindig kevésbé nyitott a gyártó cégek megismerésére. Ez magyarázható azzal, hogy hazánkban (és alapvetően világszerte) az FMCG iparon belül a vállalati márka építése nem jellemző. Magyarországon a fogyasztók sokkal inkább termékekhez kötődnek, nem pedig márkákhoz, mivel örömmel próbálnak ki különböző fogyasztói cikkeket és nem szükségszerűen társítják a minőséget a márkás termékekhez.

A kérdőív eredménye kihangsúlyozta, hogy a korábban megszerzett információk azokra van nagy befolyásoló hatással, akik fontosnak találják, hogy tudják, melyik cég termékét vásárolják meg. Mások ajánlása - főleg a barátoké és a családé -a leginkább befolyásoló tényező a vásárlási döntésben és a gyártó vállalatokkal kapcsolatos vélemény formálásában. A fókuszcsoportos vizsgálatban résztvevők is kijelentették a saját tapasztalataik fontosságát a fogyasztói cikkekkel kapcsolatban.

Ezért amellett, hogy fenntartják a termékek magas minőségi szintjét, az FMCG vállalatoknak referenciaszemélyeket kellene alkalmazniuk, akik a vállalat nagyköveteivé válnának. Általuk a fogyasztók hajlandóak lennének bizalmat fektetni a termékekbe és megismerkednének magával a vállalattal (ami segít építeni a vállalati márkát). Ahhoz, hogy rávegyék a fogyasztókat a cég termékeinek kipróbálására, mintákat küldhetnének minden háztartásnak egy személyre szóló üzenettel, amely magába foglalná a vállalat nevét/logóját, hogy erősítse a vállalati márkát is, hogy még hatékonyabb legyen az üzenet.

Az interneten elérhető információnak szintén nagy szerepe van a fogyasztók cégekkel kapcsolatos véleményalkotásában. Ennek megfelelően, a vállalatok weboldalainak informatívnak, folyamatosan frissítettnek és ergonómikusnak kell lenniük. Ahogy azt a fókuszcsoportos vizsgálat is kiemelte, a válaszadók értékelő oldalakat is felkeresnek, ahol a fogyasztók megosztják a tapasztalataikat a termékekkel és a cégekkel.

Az előző állítással kapcsolatban szintén fontos kiemelni a botrányok elkerülésének fontosságát, mivel a válaszadók azt állították, hogy a rossz hírek nagyon könnyen eredményezhetik a vállalat mellőzését.

Az FMCG cégek a missziót és a víziót nem kommunikálják közvetlenül és a legtöbb fogyasztó nem ismeri fel, azonban a legtöbb magyar fogyasztó azt állítja, hogy ezeket tudatosan kellene közvetíteniük. 
Ez az eredmény azt is mutathatja, hogy a jövőben a fogyasztók sokkal befogadóbbak lesznek ezekkel szemben.

Végül megállapítottuk, hogy mindkét vizsgált cég jól ismert Magyarországon és a fogyasztók a termékmárkáikat magas minőséggel párosítják. Amellett, hogy elégedettek a termékekkel, a fogyasztók egy része a vizsgált cégek marketingkommunikációját is hatékonynak találják. Mindkét vizsgált szervezet vállalati márkájával kapcsolatos reklámja többnyire összhangban volt a vállalat missziójával, víziójával és értékeivel. Továbbá a válaszadók kifejezték a minőségi reklámok iránti igényüket, ezért ezeknek a multinacionális vállalatoknak folytatniuk kellene a vállalati márkájuk erősítését igényes reklámokkal, amelyek mélyebb üzeneteket hordoznak.

Habár még csak a fogyasztók kis része fogékony a vállalati márkázásra, de véleményünk szerint megéri erre nagyobb hangsúlyt fektetni, mivel ezáltal a fogyasztók jobban kötődhetnek a céghez, ami árbevétel növekedést eredményezhet.

\section{Hivatkozások}

[1] A. Alizadeh, A. Moshabaki, S. Hoseini, A. Naiej (2014), The Comparison of Product and Corporate Branding Strategy: a conceptual framework, IOSRJournal of Business and Management, Vol. 16, Issue 1. Ver. IV. pp. 16-17.

[2] P. Argenti, B. Druckenmiller (2004), Reputation and the Corporate Brand, Corporate Reputation Review. Vol.6. No.4. pp. 368-369.

[3] M. Hatch, M. Schultz (2003), Bringing the corporation into corporate branding, European Journal of Marketing, Vol. 37, No. 7/8, pp. 1041-1064.

[4] R. Jones (2010), Corporate branding: the role of vision in implementing the corporatebrand, Innovative Marketing, Vol. 6, Issue 1, pp. 44-57.

[5] S. Knox, SD. Bickerton (2013), The Six Conventions of Corporate Branding, European Journal of Marketing, Vol. 37, No. 7-8, pp. 998-1016.

[6] C. R. Kothari (2004), Research Methodology: Methods and Techniques, New Age International (P) Ltd., Publishers., New Delhi, 418 p. (ISBN: 812-2424-88-0)

[7] S. Madhavaram, V. Badrinarayanan, R. McDonald (2005), Integrated marketing communication (IMC) and brand identity as critical components of brandequity strategy, Journal of Advertising, Vol. 34, No. 4, pp. 69-80.

[8] R. Panneerselvam (2004), Research Methodology, Prentice-Hall of India Private Limited, New Delhi, 528 p. (ISBN: 812-0324-52-8)

[9] W. Shandwick (2011), The Company behind the brand: inreputation we trust, Weber Shandwick, pp. 22. 